\title{
ДО ПИТАННЯ ОРГАНІЗАЦІЇ ПРОГРАМИ РЕАБІЛІТАЦІЇ ХВОРИХ 3 ІШЕМІЧНОЮ ХВОРОБОЮ СЕРЦЯ ПІСЛЯ ХІРУРГІЧНОЇ РЕВАСКУЛЯРИЗАЦІЇ МІОКАРДА В ОДЕСЬКІЙ ОБЛАСТІ
}

\author{
ДУ «Український НДІ медичної реабілітації та курортології МОЗ України», м. Одеса, Україна
}

\begin{abstract}
Мета: проаналізувати розповсюдженість ішемічної хвороби серця в Одеській області та обґрунтувати організаційну модель відновлювального лікування хворих з ішемічною хворобою серця після перенесеної хірургічної реваскуляризації.

Матеріали і методи. Вивчали офіційні статистичні дані (звітна документація про стан захворюваності за період з 2010 до 2016 р. в Одеській області та дані Центру медичної статистики МОЗ України).

Результати. Смертність на 100 тис. населення від хвороб системи кровообігу в 2016 р. збільшилась на 3,6 \%, від ішемічної хвороби серця - на 2,6 \%, від інсраркту міокарда - на 11,2 \%. Кількість операційних втручань 3 приводу реваскуляризації міокарда в Одеській області зросла, а, також зросла і післяопераційна летальність після проведення хірургічної реваскуляризації міокарда і у 2015 р. була найвищою (5,6 \%) порівняно із загальноукраїнськими показниками.

Висновки. Активне впровадження нових методів лікування ішемічної хвороби серця, зокрема хірургічної реваскуляризації міокарда потребує розробки системи відновлювального лікування пацієнтів цієї категорії, а також системи вторинної профрілактики прогресування ішемічної хвороби серця.
\end{abstract}

КЛЮчОВІ СЛОВА: ішемічна хвороба серця; хірургічна реваскуляризація; захворюваність; програми реабілітації.

Хвороби системи кровообігу (ХСК) займають перше місце в структурі загальної захворюваності та друге місце в структурі первинної захворюваності населення України. Найбільш визначальною та соціально значущою серед ХСК за поширеністю залишається ішемічна хвороба серця (IXC) (33,7 \%) [1]. Саме дана нозологія має найвищі темпи приросту. За період 2001-2011 рр. поширеність IXC зросла майже у 2 рази [6]. IXC - це захворювання 3 тривалим, хронічним перебігом, а хірургічна реваскуляризація міокарда (ХРМ) (аорто-коронарне шунтування, стентування коронарних артерій) це один 3 етапів лікування, якому передує та за яким наступає раціональна структура лікувальнореабілітаційної допомоги $[7,8]$. Як відомо, хворі після операції із реваскуляризації міокарда повинні пройти певні етапи лікування: ранній та пізній госпітальний етап та санаторний [9]. У той же час, аналіз даних літератури та власний досвід свідчить про те, що на етапному відновлювальному лікуванні системний підхід до здійснення лікувальних впливів ще не отримав повною мірою належного розвитку та застосування. Особливо мало уваги приділяють санаторному етапу, який є найбільш тривалим та від якого залежить ефективність відновлювального лікування пацієнтів.

(c) О.В. Колоденко, 2017
Мета дослідження: проаналізувати розповсюдженість IXC та кількість операційних втручань при цій патології в Одеській області; виявити коморбідну патологію та обґрунтувати організаційну модель відновлювального лікування у хворих з IXC та супутньою патологією після перенесеної хірургічної реваскуляризації.

Матеріали і методи. Вивчали офіційні статистичні дані (звітна документація про стан захворюваності за період з 2010 до 2016 р. в Одеській області та дані Центру медичної статистики МОЗ України щодо захворюваності та поширеності хвороб серцево-судинної системи та кількість операційних втручань для реваскуляризації міокарда). У роботі використано метод системного аналізу та статистичний метод дослідження.

Результати дослідження та їх обговорення. В Україні, за даними Центру медичної статистики МОЗ України, кількість дорослих, які страждають від ХСК складає майже 40 \% населення. Серед них, найрозповсюдженішою $є$ IXC, яка займає перше місце в структурі смертності від ХСК [5]. У 2014 р. смертність від цього класу причин смерті досягла 989,8 осіб на 100 тис. населення і порівняно 3 2011 р. зросла на 1,6 \%. Аналогічну картину ми спостерігали і в Одеській області, а саме при вивченні стану захворюваності населення Одеської області 
за період 2010-2016 рр. серцево-судинна патологія залишається однією з основних причин захворюваності та смертності (табл. 1). Якщо в 2012 р. кількість померлих від ХСК дорівнювала 900,5 на 100 тис. населення, то у 2016 р. цей показник збільшився на 3,5 \%. Також збільшилась смертність від IXC на 100 тис. населення на 2,6 \% та від інсраркту міокарда (IM) - на 11,2 \% в 2016 р. порівняно з 2012 р.

При вивченні захворюваності та поширеності ХСК в Одеській області ми спостерігали зниження кількості хворих з цією патологією протягом останніх трьох років, але незважаючи на це, все ж таки залишається вище загальноукраїнських. Найбільше зниження було відмічено в 2014 р. на 1,8\% поширеності та на 6,9 \% - захворюваності на ХСК (табл. 2).

Частка ішемічної хвороби серця у структурі загальної смертності, на жаль, кожного року збільшується (рис. 1) і в 2016 р. становить 66,1 \%, що на 3,1 \% більше ніж у 2010 р. Смертність від IXC у 2010 р. склала 37,9 \%, в 2011 р. цей показник знизився на рівень 33,53 \%, але потім кожного року ми спостерігали збільшення цього показника максимальне в 2015 р. до 38,2 \%.

Таблиця 1. Смертність населення Одеської області від хвороб системи кровообігу, в тому числі ішемічної хвороби серця у період 2012-2016 рр. (на 100 тис. населення)

\begin{tabular}{|c|c|c|c|c|c|c|c|c|c|c|}
\hline \multirow{2}{*}{ Нозологія } & \multicolumn{5}{|c|}{ Абсолютні дані } & \multicolumn{5}{|c|}{ Показники на 100 тис. населення } \\
\hline & 2012 & 2013 & 2014 & 2015 & 2016 & 2012 & 2013 & 2014 & 2015 & 2016 \\
\hline $\mathrm{XCK}$ & 21407 & 21549 & 22348 & 22916 & 22180 & 900,5 & 903,9 & 936,9 & 960,7 & 932,2 \\
\hline у т. ч. IXC & 12172 & 12285 & 12768 & 13229 & 12499 & 512,0 & 515,3 & 535,2 & 554,6 & 525,3 \\
\hline IM & 531 & 577 & 546 & 594 & 589 & 22,3 & 24,2 & 22,9 & 24,9 & 24,8 \\
\hline
\end{tabular}

Таблиця 2. Поширеність та захворюваність на хвороби системи кровообігу в Одеській області за період 2013-2016 рр. на 100 тис. дорослого населення

\begin{tabular}{|c|c|c|c|c|c|c|}
\hline \multirow{2}{*}{ Рік } & \multicolumn{3}{|c|}{ Поширеність } & \multicolumn{3}{|c|}{ Захворюваність } \\
\cline { 2 - 7 } & $\begin{array}{c}\text { абсолютні } \\
\text { дані }\end{array}$ & $\begin{array}{c}\text { показник } \\
\text { на 100 тис. } \\
\text { населення }\end{array}$ & $\begin{array}{c}\text { частка від } \\
\text { хвороб системи } \\
\text { кровообігу }\end{array}$ & $\begin{array}{c}\text { абсолютні } \\
\text { дані }\end{array}$ & $\begin{array}{c}\text { показник на } \\
100 \text { тис. } \\
\text { населення }\end{array}$ & $\begin{array}{c}\text { частка від } \\
\text { хвороб системи } \\
\text { кровообігу }\end{array}$ \\
\hline 2013 & 1467808 & 61566,5 & 31,7 & 138430 & 5806,4 & 8,1 \\
\hline 2014 & 1440785 & 60399,3 & 32,0 & 128972 & 5406,6 & 7,8 \\
\hline 2015 & 1421580 & 59595,5 & 32,0 & 127827 & 5358,8 & 7,8 \\
\hline 2016 & 1390024 & 58423,3 & 31,5 & 126305 & 5308,7 & 7,7 \\
\hline
\end{tabular}

\begin{tabular}{|c|c|c|c|c|c|c|}
\hline 63,94 & 63,53 & 63,62 & 64,28 & 65,43 & 66,32 & 66,07 \\
\hline 37,96 & & 36,17 & 36,65 & 37,38 & 38,28 & 37,23 \\
\hline \multicolumn{7}{|c|}{ - - - - - - - - - - - - - - - } \\
\hline 1,67 & 1,55 & 1,58 & 1,77 & 1,6 & 1,72 & 1,75 \\
\hline \multicolumn{7}{|c|}{ } \\
\hline \multirow[t]{2}{*}{2010} & 2011 & 2012 & 2013 & 2014 & 2015 & 2016 \\
\hline & & \multicolumn{4}{|c|}{$\begin{array}{l}\text { хвороби системи кровообігу } \\
\text { у т. ч. ІХС } \\
\text { гострий та повторний інфаркт міокарда }\end{array}$} & \\
\hline
\end{tabular}

Puc. 1. Структура смертності від хвороб системи кровообігу в Одеській області за період 2010-2016 рр. (\%). 
При аналізі кількості операційних втручань 3 приводу реваскуляризації міокарда було виявлено, що кількість стентування коронарних артерій за досліджуваний період в Одеській області зросла на 20,5 \%, а рівень операційних - на 28,1 \%, також зросла і післяопераційна летальність після проведення ХРМ і у 2015 р. була найвищою (5,6 \%) порівняно із загальноукраїнськими показниками.

Проведена в ході дослідження експертна оцінка показала, що провідними причинами зниження ефективності ХРМ є: низький рівень діагностики супутньої патології, відсутність заходів, що підвищують мотивацію хворих до реабілітації, низький рівень психологічної діагностики, відсутність диореренційованих комплексів відновлювального лікування після ХРМ та заходів щодо вторинної проорілактики IXC.

На нашу думку, в сучасних умовах така система організації може бути реалізована на основі створення програм, які об'єднують як лікувально-профрілактичні заходи, спрямовані на швидке та ефрективне одужання після ХРМ, так і навчання хворих ефективному самоконтролю та модифікації способу життя. На сьогодні це завдання не вирішено повною мірою на амбулаторному етапі. Окрім того, немає системи моніторингу критеріїв ефективності лікування та якості відновлювального лікування при тривалому динамічному спостереженні.

\section{Висновки}

Хвороби системи кровообігу в Одеській області за період 2010-2016 рр. були основною причиною смерті. Активне впровадження нових методів лікування IXC, зокрема XPM потребує розробки системи відновлювального лікування пацієнтів цієї категорії, а також системи вторинної профілактики прогресування IXC.

Перспективи подальших досліджень полягають у розробці системи моніторингу критеріїв та якості відновлювального лікування хворих з IXC після ХРМ.

\section{Список літератури}

1. Кудря І. П. Оцінка перебігу та якості життя у хворих на ішемічну хворобу серця після стентування коронарних артерій / І. П. Кудря, Т. І. Шевченко // Актуальні проблеми сучасної медицини. - 2014. - Т. 14, вип. 2. - С. 19-22.

2. Показники здоров'я населення та діяльності закладів охорони здоров'я за 2015-2016 роки / МО3 України, КУ «Обласний інорормаційно-аналітичний центр медичної статистики». - Одеса, 2017. - 390 с.

3. Показники здоров'я населення та діяльності закладів охорони здоров'я за 2013-2014 роки / МО3 України, КУ «Обласний інфрормаційно-аналітичний центр медичної статистики». - Одеса, 2015. - 356 с.

4. Показники здоров'я населення та діяльності закладів охорони здоров'я за 2011-2012 роки / МО3 України, КУ «Обласний інфрормаційно-аналітичний центр медичної статистики». - Одеса, 2013. - 338 с.

5. Показники здоров'я населення та використання ресурсів охорони здоров'я в Україні за 2015 рік : довідник / МОЗ України, Центр медичної статистики. - К., 2016. - 285 с.

6. Теренда Н. О. Основні тенденції та прогнозні оцінки загальної та первинної захворюваності на ішемічну хворобу серця в Україні / Н. О. Теренда // Вісник соціальної гігієни та організації охорони здоров'я України. - 2016. - № 3 (69). - C. 31-35.

7. Теренда Н.О. Впровадження методу стентування коронарних артерій в Україні / Н. О. Теренда // Вісник соціальної гігієни та організації охорони здоров'я України. - 2016. - № 4 (70). - С. 12-17.

8. ESC Guidelines on myocardial revascularization // Eur. Heart J. - 2010. - Vol. 31. - P. 2501-2555.

9. Salim Yusuf. Deciphering the causes of cardiovascular and other complex diseases in populations: achievements, challenges, opportunities, and approaches / Yusuf Salim, Anand Sonia // Progress in Cardiovascular Diseases. - 2010. Vol. 53, No. 1. - P. 62-67.

\section{References}

1. Kudria, I.P. \& Shevchenko, T.I. (2014). Otsinka perebihu ta yakosti zhyttia u khvorykh na ishemichnu khvorobu sertsia pislia stentuvannia koronarnykh arterii [Evaluation of clinical course and quality of life in patients with coronary heart disease after coronary artery stenting]. Aktualni problemy suchasnoi medytsyny - Actual Problems of Modern Medicine, 14 (2), 19-22 [in Ukrainian].

2. Pokaznyky zdorovia naselennia ta diialnosti zakladiv okhorony zdorovia za 2015-2016 roky [Indicators of public health and activities of health facilities for 2015-2016 / Ministry of Health of Ukraine]. (2017). Odesa: MOZ Ukrainy, KU "Oblasnyi informatsiino-analitychnyi tsentr medychnoi statystyky" [in Ukrainian].

3. Pokaznyky zdorovia naselennia ta diialnosti zakladiv okhorony zdorovia za 2013-2014 roky [Indicators of public health and activities of health facilities for 2015-2016]. (2015). Odesa: MOZ Ukraiiny, KU "Oblasnyi informatsiino-analitychnyi tsentr medychnoi statystyky" [in Ukrainian].

4. Pokaznyky zdorovia naselennia ta diialnosti zakladiv okhorony zdorovia za 2011-2012 roky [Indicators of public health and activities of health facilities for 2015-2016]. (2013). Odesa: MOZ Ukrainy, KU "Oblasnyi informatsiino-analitychnyi tsentr medychnoi statystyky" [in Ukrainian].

5. Pokaznyky zdorovia naselennia ta vykorystannia resursiv okhorony zdorovia v Ukraini za 2015 rik: dovidnyk [Indices of health and the use of health resources in Ukraine for 2013: reference book]. (2016). Kyiv: MOZ Ukrainy, Tsentr medychnoi statystyky [in Ukrainian].

6. Terenda, N.O. (2016) Osnovni tendentsii ta prohnozni otsinky zahalnoi ta pervynnoi zakhvoriuvanosti na ishemichnu khvorobu sertsia $v$ Ukraini [Main tendencies and prognostic estimates of the general and primary morbidity of ischemic 
heart disease in Ukraine]. Visnyk sots. hihiieny ta orh. okhorony zdorovia Ukrainy - Journal of Social Hygiene and Health Protection Organization of Ukraine, 3 (69), 31-35 [in Ukrainian].

7. Terenda N.O. (2016) Vprovadzhennia metodu stentuvannia koronarnykh arterii v Ukraini [Introduction of the method of stenting coronary arteries in Ukraine]. Visnyk sots. hihiieny ta orh. okhorony zdorovia Ukrainy - Journal of Social Hygiene and Health Protection Organization of Ukraine, 3 (69), 31-35 [in Ukrainian].

8. European society of Cardiology. (2010). Guidelines on myocardial revascularization. European Heart Journal, 31, 25012555. European society of cardiology

9. Salim Yusuf \& Anand Sonia. (2010). Deciphering the causes of cardiovascular and other complex diseases in populations: achievements, challenges, opportunities, and approaches. Progress in Cardiovascular Diseases, 53 (1), 62-67.

\section{К ВОПРОСУ ОРГАНИЗАЦИИ ПРОГРАММЫ РЕАБИЛИТАЦИИ БОЛЬНЫХ С ИШЕМИЧЕСКОЙ БО- ЛЕЗНЬЮ СЕРДЦА ПОСЛЕ ХИРУРГИЧЕСКОЙ РЕВАСКУЛЯРИЗАЦИИ МИОКАРДА В ОДЕССКОЙ ОБ- ЛАСТИ \\ Е.В. Колоденко \\ ГУ «Украинский НИИ медицинской реабилитации и курортологии МЗ Украины», г. Одесса, Украина}

Цель: проанализировать распространенность ишемической болезни сердца в Одесской области и обосновать организационную модель восстановительного лечения у больных с ишемической болезнью сердца после перенесенной хирургической реваскуляризации.

Материалы и методы. Изучали официальные статистические данные (отчетная документация о состоянии заболеваемости за период с 2010 до 2016 г. в Одесской области и данные Центра медицинской статистики МЗ Украины).

Результаты. Смертность на 100 тыс. населения от болезней системы кровообращения в 2016 г. увеличилась на 3,6 \%, от ишемической болезни сердца - на 2,6 \%, от инфаркта миокарда - на $11,2 \%$. Количество операционных вмешательств по поводу реваскуляризации миокарда в Одесской области выросла, а также выросла и послеоперационная летальность после проведения хирургической реваскуляризации миокарда и в 2015 г. была самой высокой (5,6 \%) по сравнению с общеукраинскими показателями.

Выводы. Активное внедрение новых методов лечения ишемической болезни сердца, в частности хирургической реваскуляризации миокарда требует разработки системы восстановительного лечения пациентов этой категории, а также системы вторичной профилактики прогрессирования ишемической болезни сердца.

КЛЮЧЕВЫЕ СЛОВА: ишемическая болезнь сердца; хирургическая реваскуляризация; заболеваемость; программы реабилитации.

\section{TO THE QUESTION OF ORGANIZING REHABILITATION PROGRAM IN PATIENTS WITH ISCHEMIC HEART DISEASE AFTER SURGICAL MYOCARDIAL REVASCULARIZATION IN ODESA REGION \\ O.V. Kolodenko \\ Ukrainian Research Institute of Medical Rehabilitation and Balneology, Odesa}

Purpose: to analyze the prevalence of ischemic heart disease (IHD) in Odesa region and to substantiate the organizational model of restorative treatment in patients with IHD after surgical revascularization.

Materials and Methods. Official statistical data were studied (reporting documentation on the state of morbidity for the period from 2010 to 2016 in Odesa region and data from the Medical Statistics Center of the Ministry of Health of Ukraine).

Results. Mortality per 100 thousand of the population from diseases of the circulatory system in 2016 increased by $3.6 \%$, from IHD - by $2.6 \%$, from myocardial infarction - by $11.2 \%$. The number of surgical interventions for revascularization of the myocardium in Odesa region has increased, and postoperative mortality after the surgical myocardial revascularization has also increased, and in 2015 it was the highest (5.6\%) in comparison with the allUkrainian indices.

Conclusions. The active introduction of new methods for the treatment of IHD, in particular surgical myocardial revascularization, requires the development of a rehabilitative treatment system for this category of patients, as well as a system for the secondary prevention of IHD progression.

KEY WORDS: ischemic heart disease; surgical revascularization; morbidity; rehabilitation programs.

Рукопис надійшов до редакції 04.09.2017 p.

\section{Відомості про автора:}

Колоденко Олена Володимирівна - кандидат медичних наук, докторант ДУ «Український НДІ медичної реабілітації та курортології МОЗ України»; тел. +38(067)921-65-37. 